a (1) (n)

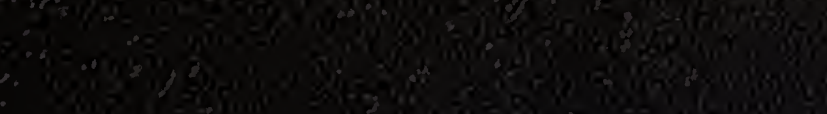

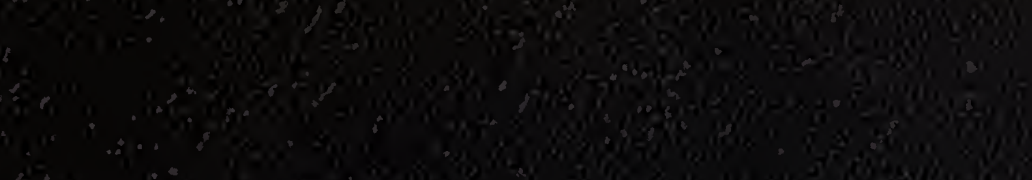
(3)

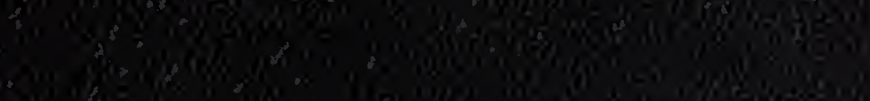

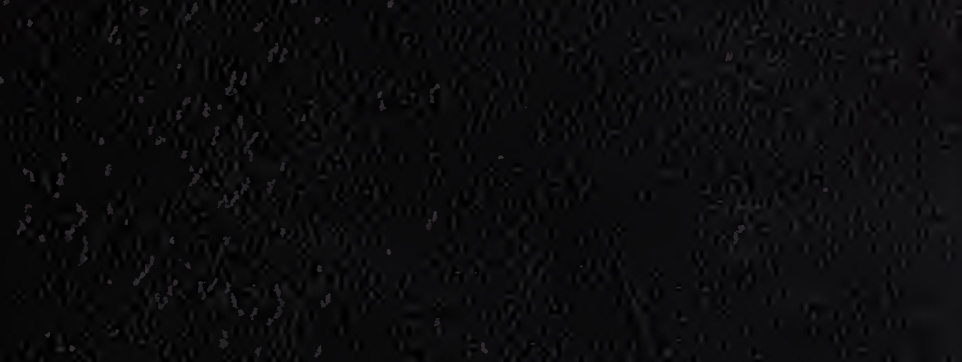
$x_{i} x_{3}$ , 


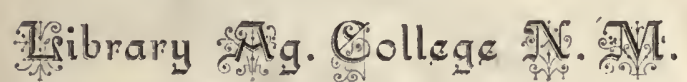

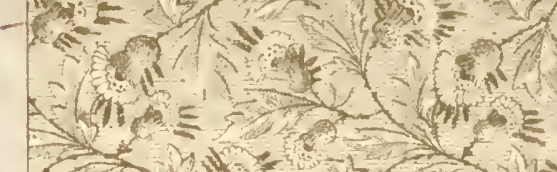
A sift from lle. Ag Exh Stan Received finne 23, 1892 $=2 x-10 n=0$
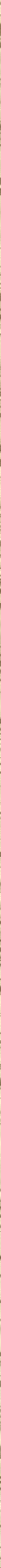






\section{UNIVERSITY OF ILLINOIS,}

\section{Agricultural Experiment Station.}

CHAMPAIGN, FEBRUARY, 1891.

BULLETIN NO. 15.

\section{THE FRUIT BARK BEETLE.}

(Scolytus rugulosus, Ratz.)

ORDER COLEOPTERA. FAMILY SCOLYTIDA.

The discovery made in June, 1888 , by an assistant of the office, of the occurrence in southern Illinois of a European fruit-tree insect not hitherto known in this state, and the publication the following year of an article on the subject in the Transactions of the State Horticultural Society, ${ }^{*}$ seem to have led to a somewhat general examination of fruit trees thr oughout the region interested, with the result to show that this insidious insect was not only somewhat widely distributed, but that it had evidently been for some years at work. This fact became almost alarmingly ap parent at the meeting of the State Horticultural Society at Cairo in Dece mber, 1890 , when the presentation of specimens of the injury and a general comparison of experiences made the horticulturists present personally acquainted with this subject. A special committee of the Society was appointed there, which prepared resolutions requesting immediate legislation for the destruction of this insect; but on discussion, these resolutions were changed to one of reference to the State Entomologist, with the request that he recommend such action concerning the matter as he might deem advisable. Fruit-growers of long experience in that part of the state have, in fact, become apprehensive of serious loss, one going so far as to say that unless prompt and decisive action is taken, every orchard in southern Illinois is doomed. $\dagger$ While these fears are probably somewhat extreme, as is likely to be the case on the first discovery of a new attack, it is evident that the subject should receive immediate and thorough-going investigation, and I prepare this article with the

*Trans. Ill. Hort. Soc., 1889 (v. 23), p. 245.

tSee letter from Mr. Theodore Goodrich in Frairic Farmer, January 10, 7891, p. 20; also in Orange Fudd Farmer of same date, p. 28. 
view of presenting an exhaustive summary of everything of importance known concerning this insect and its work, as a basis for intelligent investigation and experiment.

History in Illinois.

The fruit bark beetle was first observed in this state by my assistant, Mr. John Marten, June 15 , I888, while on an entomological trip from the office through southern Illinois. Specimens of damaged plum twigs were handed him by a gentleman at Albion, Edwards county, who had noticed an apparent blight of the trees in his village door-yard, which, upon examination, seemed to be due to insect injury. The twigs were dried and shriveled for six or more inches from the tops, and most of the leaves had fallen, the remainder being withered and yellow. Close examination showed minute holes like pin pricks at the bases of several of the buds, these leading into longitudinal burrows about the diameter of a pin, running mostly lengthwise under the bark. Dead beetles found in the burrows, somewhat cursorily examined by Mr. Marten, were identified by him as the so-called "pear blight beetle," Xyleborus pyri, and so published in the Prairie Farmer for December I5, I 888 (p. 818), but a later examination, made at the office the following spring, showed that the beetle was Scolytus rugulosus.

It was next brought to my attention by a letter from Mr. George W. Endicott, of Villa Ridge, Pulaski county, written in response to a circular request to horticulturists, issued February 16, 1889, for information on any subject in horticultural entomology which seemed to require fresh investigation. In this letter the beetle was said to work on the trunks of wild goose and other plums of the Chickasaw family, boring numerous round holes, and laying eggs which hatched small white worms that completely girdled the tree in a single year. Later in this month specimens were received from Mr. Endicott; two pieces. of affected plum trees, one a section of a trunk four inches in diameter, and the other a branch one and a fourth inches through, the latter dead, and the bark everywhere perforated with numerous circular holes I to I I $/ 4 \mathrm{~mm}$. in diameter. These were most numerous in the old leaf scars, as many as six to a single scar, but were elsewhere uniformly but irregularly distributed, averaging perhaps five or six to the square inch. The bark was thoroughly undermined by burrows of about the same size as the openings made in the deeper portion of the bark and the outer part of the sap wood, so as to give the surface when the bark was removed a grooved appearance, most of the grooves running irregularly lengthwise. On carefully cutting the bark from about three square inches, fragments of a dead beetle were discovered, together with eight living full-grown larvæ and a single pupa - this last a point of special interest as bearing.upon the life history of the species.

Next, at Fairfield, Illinois, May ıo, I 890 , adult beetles were found alive in the bark of apple trees. Others were seen flying in the orchard 
and alighting on the trees, as shown by specimens caught in the fingers. They were flying swiftly and freely, as if capable of protracted flights.

Immediately on my return from the horticultural meeting last December, Mr. Marten was sent on a trip through the southern part of the state, to make a careful field study of the work, and distribution of the fruit bark beetle in the principal fruit-growing districts. His notes of the trip are given here somewhat fully as bearing upon the following important questions: Does this fruit beetle attack perfectly healthy trees, or has it the habit, quite common among borers, of selecting by preference those already diseased? Can these injurious insects be now exterminated in Illinois either by co-operative or compulsory measures?

At Villa Ridge, on the grounds of Mr. E. J. Ayers, two peach trees were found af. fected-not as yet very badly damaged. One of these trees was, however, partly dead from some other cause. The affected plum trees (Chickasaws) on Mr. Endicott's place had been imported from New Jersey in $1883^{*}$ and were believed to have been attacked in 1885 or 1886 , when two or three years old, but the insects themselves were not detected until 1887. Plum-trees from Texas were next infested, and also a few peach-trees adjacent, probably by beetles from the New Jersey stock. All these trees having been cut down and burned, none of the fruit beetles were then to be found in the immediate vicinity. Elsewhere on the same premises, however, a Mariana plum injured by a wagon in the spring was completely riddled, and seemingly healthy trees likewise showed a few punctures. One dead tree full of holes contained no beetles.

Four additional places were visited at Villa Ridge, in which plum-, peach-, and cherry-trees were found infested. The work of the beetle was also recognized in peachtrees cut down the year before, but these contained no larvæ at the time. Two vigorous peach-trees, which showed the characteristic perforations very thickly placed, did not have the bark undermined; but these trees had bled very freely, the gum having run down the trunks to the ground in considerable quantities. It would seem from this observation, supported by a section of the trunk brought to the office, that the peach-tree may repel the beetle, or prevent the hatching of its eggs at least, at some times and under some conditions, by a free exudation of its gummy sap.

At Anna, in Union county, this pest was found abundant and destructive, infesting the plum, in which the larvæ varied in development from half to full grown, occurring also in the cherry, even down to twigs under a quarter of an inch in diameter, and, on the farm of Mr. Fuller, badly infesting large Ben Davis apple-trees, either dead or dying. The condition of these trees and the amount of injury by the bark beetle gave the obser. ver the impression that the trees were damaged before the insect attack. Several peachtrees were also attacked on these premises. One of the plum-trees here noticed had evidently been first attacked in an injured limb. Woodpeckers were said to have stripped the bark off many dead limbs in their search for larvæ. By Dr. Pickles, of Anna, identical injuries were reported to occur on twelve other fruit farms within his knowledge, at this place.

At Cobden, two places were visited where several apparently unhealthy apple-trees were badly infested, one of them nearly denuded of bark by birds. Here also peach-, plum-, and cherry-trees had been attacked.

At Makanda, Jackson county, several plum-trees were found very full of holes, some of them completely riddled and-apparently practically killed. Peach-trees here were also badly affected, but none of the injury was found in wild fruits of any kind, nor yet in nursery stock.

At Du Quoin, in two places visited, plum-trees were injured, some seriously, others slightly; and at Centralia, in the orchard of Mr. Jabez Webster, President of the State

*As the beetle had been reported from New Jersey some years before, it is very likely that it was brought in these trecs to Mr. Fndicott's place directly from there. 
Horticultural Society, the larvæ of the beetles and their work were found in plum-, cherry-, and apple-trees, the first most seriously damaged. In the apple, however, they occurred only in branches previously injured or diseased. Several cherry-trees in different parts of the town were quite badly infested.

From Tonti to Odin, only a single affected tree was found, and that a peach, the wild plum-and cherry-trees by the roadside, and the apple-trees in the orchards seeming free from injury. At Albion, in Edwards county, the larva was found repeatedly in cherry, plum, and apple, the plum-trees suffering badly, one of them killed and stripped by birds. At Olney the fruits already mentioned were similarly injured, the plum and peach most; and on one place here young plum-trees were affected. At Fairfield, in Wayne county, four places were visited, and beetles found in all, in each of the usual fruits. Here an injury to young apple-trees was noticed, 一the only instance seen.

No observations were made at that time west of the line of the Illinois Central Railroad, but its probable occurrence in this region is shown by a communication from Prof. Herbert Osborn, of Iowa, published in the Orange Fudd Farmer, of Chicago, for Jan. I0, $189 \mathrm{I}$ (p. 20), in which he mentions the receipt from a correspondent at Girard, Macoupin county, Illinois, of portions of an injured plum-tree showing quite evidently the work of the fruit bark beetle; and I have since learned of its presence south of Belleville, in St. Clair county, and at Alton, in Madison county.

\section{History in the United States at Large.*}

This insect seems to have been first observed in the United States about the year 1877 , and was first reported from Elmira, New York, where it had done noticeable injury to peach-trees. In $\mathrm{8} 880$, Dr. Riley mentioned its occurrence at Fairhaven, New Jersey; in Coopersburg, Pennsylvania; Hillsboro, Missouri; Williamsport, Maryland; and the District of Columbia. At Fairhaven it had destroyed all the cherry-, peach-, and plum-trees. set out on a particular lot; in Pennsylvania it had injured the cherry; and in Missouri and Maryland it had attacked also the peach. In r884, Dr. Hagen, of the Harvard University Museum, discovered it in the larger branches of young pear-trees at Cambridge; and the same year it was reported from Georgia - the specimens being determined by Dr. Riley-as occurring in pear, apple, peach, and plum. In r885, Dr. John Hamilton, of Allegheny, Pennsylvania, made the surprising statement that he had obtained this insect twice by breeding from hickory-twigs; but Mr. E. A. Schwarz, of the U. S. National Museum, to whom the specimens were referred, reported later that they were not $S$. rugulosus, but a species apparently undescribed. (Proc. Ent. Soc. Wash., I., r886, p. 30.) In South Carolina it infested peach, plum, and cherry in $x 885$ and r886, and did considerable damage in that state. One, and possibly two, hymenopterous parasites of the larvæ were here bred from it by Prof. Atkinson. These parasites were found quite common in larvæ infesting the peach, and are of especial interest as the first indication, of any natural check, upon the multiplication of this species. $\uparrow$ The fact that it is

*A recent letter from Dr. Riley gives me the following additional dates and localities taken from his correspondence and collections:

Ammendale, Md., October, 1881, from plum ; Marlboro, N. Y., November 16, 1881; Macon, Ga., October $5, x 883$, on pear; Glendale, Md., April 9, 1884, on plum: Wading River, N. Y., March 18, 1884, on cherry; Junction P. O., Va., October 2, 1885 ; Mt. Vernon, Ind., June 24, 189o, on peach; New Lexington, Pa., July 7, 1890, on pear; LaFayette, Ind., August 15, 1890, on peach.

tMany of the larva now in the office in bark of trees are clearly parasitized, but the parasites have not been bred. 
not considered very seriously injurious in Europe, where it has long been known, makes it very likely that it is kept in check there by parasites, and gives ground for the hope that parasitism here may presently put a stops to its increase.

European Accounts.

In the present incomplete state of our knowledge of the habits and history of this insect and of the variety and extent of its injuries, some of the particulars of its European history will serve at least a temporary purpose.

Over fifty years ago it was recognized in Germany as injurious to the apple, and the best biography of it which $\mathrm{I}$ have yet seen is that published by Schmidberger in 1837 in Köllar's Treatise on Insects-his relation being based on the methodical observation of specimens bred in apple twigs for one entire year, from May, I834, to May, I835.

According to the fullest European account of their injuries within my reach as I write,- - that contained in Taschenberg's Practical Entomology,-these beetles infest, in Germany, the apple, plum, cherry, peach, and quince, occurring more frequently in the branches than in the trunk. The adult makes its appearance in May, but fresh burrows may be found as late as October-a fact which may be explained either as an indication of a second brood, or of long-continued injuries by a single generation. The female perforates the bark and, after pairing in the anterior part of her nearly vertical breeding chamber, burrows longitudinally, laying eggs to the right and left as she goes. The larvæ hatching, eat laterally outward, forming nearly straight channels, furrowing the sap wood more or less, unless the bark be thick, and forming finally a pupal chamber in the wood. Larvæ from the eggs earliest laid are said by Taschenberg to com plete their transformations by the end of June-a statement quite at variance with that of Schmidberger, whose beetles laid eggs in May, which, kept in his warm living room, did not finish their development until the following February, and did not come forth for further reproduction until April and May.

The only remedies suggested are the special care and fertilization of trees to enable them to repel the attack of the beetles; the destruction, in whole or in part, of trees seriously infested; or, in the case of especially valuable ones, protection by lasting repellants applied to the trunks and branches.

Kaltenbach, Eichoff, Döbner, Goureau, and Giard add nothing decisive or important to this account except to give the hawthorn, elm, and mountain ash in the list of trees infested, and to increase by their statements the probabilities of two annual broads of the beetles, instead of. the single one reported by Schmidberger.

INJURIES TO VEgETATION.

The trees now reported subject to injury by this insect are plums of various varieties, cherry, apricot, peach, pear, apple, and quince, among 
the fruits, besides the etm, mountain ash, and European hawthorn. Our personal observations and the common consent of writers on this species, both American and foreign, are to the general effect that trees are much more subject to injury if they are in an unhealthy condition, the apple particularly, in southern Illinois, seeming to be attacked only when otherwise debilitated. A single possible exception to this statement should be made of young apple-trees recently transplanted which were attacked without other signs of previous weakness than such as naturally follow a change of place. Some of the leading European writers say that this insect affects only unhealthy trees, simply aggravating their disease, whatever it may be, and hastening death. Certainly, however, in Illinois, so far as one may judge from observations already made, plum- and cherrytrees which would pass as healthy, even those still young and thrifty, sometimes suffer serious injury. On the other hand we have had occasional instances of a vigorous attack made on the trunk and branches of the peach which was apparently repelled by the great effusion of gummy sap, so that no injury has resulted except such as would follow from this profuse bleeding. It is further to be noticed that the beetles bore by preference, as is remarked by Taschenberg, in the parts of the tree or twigs where the sap flows least vigorously-a statement which will perhaps account for the curious concentration of punctures around small knots and old leaf scars, on lateral spurs, and the like. It is also very plain that a damaged branch of a healthy tree is almost certain to attract attention when this beetle is abroad, and to receive the first injury. The truth seems to be that while these insects clearly prefer weakened trees, and will continue to breed in them to some extent even after they are nearly or quite dead, they nevertheless may attack such as are really healthy and in which the flow of sap is temporarily restrained by transplanting or a relatively unthrifty growth. The stone fruits are clearly more.liable to injury than others, the plum seemingly most of all, and the peach perhaps next.

A first attack by this beetle may be made either upon the twigs and smaller branches or, as is much more commonly the case according to our observations, upon the upper part of the trunk, and the bases of the larger branches at the forks of the tree. It may extend to the very terminal twigs, those as small as an eighth of an inch in diameter, or, in the other direction, to the lower part of the trunk to within a few inches of the ground. The first conspicuous evidence of injury to the twigs is a withering of the leaves, and a shriveling of the bark similar to that caused by blight; but if the trunk or larger branches be attacked, damage to the bark may go on for some time without manifest effect upon the general appearance of the tree. Occasionally the first thing to strike the eye is a remarkable amount of gummy exudation, either on the branches. or the trunk, which may take the form of minute scattered drops, or sometimes, in the peach especially, may run down the trunk to the ground in extraordinary quantities. A closer examination will show a 
blackening of the bark where it has been undermined, and always minute round punctures half or two-thirds the diameter of the head of a common pin. Upon the twigs these punctures are most abundant at the old leaf scars, or on the thick lateral spurs, but they may occur elsewhere, and in the thicker bark of the trunk and branches seem quite irregularly distributed. If the bark is cut away, these'openings are seen to penetrate it, commonly, to the wood, the channels usually running vertically inward (sometimes a little obliquely); and if the tree be badly infested the under surface of the bark will be almost completely eaten out and marked by a net-work of fine channels of about the same diameter as the small holes already mentioned. The greater part of these grooves run lengthwise of the stem, and, except where the bark is thickest, similarly furrow the surface of the wood, so that when the tree is denuded of bark the whole surface beneath is seen to be closely engraved, as by a minute gouge. More critical examination will show here and there a broader burrow, running commonly lengthwise of the stem, nearly straight, or sometimes a little curved, and from this central, larger channel, a great number of much smaller ones will pass out to the right and left as closely as they can be placed, increasing in size as they go, and presently changing direction, so that those at first running crosswise of the stem become longitudinal. If one of the grooves on the surface of the wood be traced to its further end, one will frequently find-especially in the winter-a speck of wood dust which, when picked away, is seen to have closed the opening to a little chamber within which the footless white grub-the larva of the beetle-is securely lodged.

This description will be better understood after the method is explained by which these burrows are made. The female beetle, resorting to the tree, burrows into the bark directly inward, and then, turning lengthwise of the branch, digs a channel from half an inch to an inch and a quarter long-the larger burrow described above, called the breeding chamber-laying eggs to the right and left as she makes her way. As these eggs hatch, the young larvæ, very small at first, eat outward in all directions, forming the closely placed radiating channels already described, enlarging the burrow of course as they increase in size themselves; and finally, when they have reached their growth, each sinks itself in the sap wood to a depth scarcely greater than its own thickness, stopping the channel behind it with a little mass of wood fiber; and there it changes to the pupa stage. This terminal cell is consequently called the pupal chamber. In this little harborage the adult beetle appears and eats its way out through an opening similar to that by which the mother entered in the beginning.

It will be seen that not all the perforations (with which the bark may be as thickly peppered as if filled with a charge of fine shot) lead into the larger breeding chambers, but most of them, in fact, are exits for the escape of beetles which have matured within the wood, and lead directly into the deserted pupa chamber. 
As these beetles may, and apparently commonly do, return at once to the bark and wood of the tree from which they have just emerged, the injury may spread rapidly, with the effect to completely undermine the bark as far as it extends, by the destruction of the cambium layer. The tree is of course deadened as far as the injury goes. Birds not infrequently search these deadened places and break the bark away, or leave it hanging in shreds.

Sometimes the trunks of trees, especially the peach, will be penetrated by openings of this same sort, which do not end in burrows, but stop presently without further development. Whether these are abortive efforts to enter for breeding purposes, or simply holes dug in feeding, we are not able certainly to say. Their great number in the trunk of the peach, and the excessive bleeding which they cause, must sometimes do considerable harm, and may even so weaken the tree as to leave it subject to more serious attack. Indeed this injury to the trunk has occasionally been noticed in company with the usual burrowing and destruc. tion of bark upon the branches and twigs of the same tree.

\section{DESCRIPTION.}

The little beetle by which the pærforations are made is about one-tenth of an inch in length and one-third as wide, nearly black, exsept the tip of the wing covers and lower part of the legs, which are russet-red. It is somewhat cylindrical in general form, and under a glass of moderate power shows a clothing of yellowish hairs on head and wing covers and a minute regular grooving of the latter, with small punctures between the grooves. The thorax is also punctured and delicately margined behind and at the sides. The head is vertical, the jaws stout and short, the antennæ short and strongly clubbed.

The larva or grub, if it may be so-called, is without feet, white, transversely wrinkled, with a small brown head. The anterior segments of the body are considerably thickened, and behind these the form tapers slightly to the end. It is, like the beetle, about one-tenth of an iuch in length.

For technical uses I add a fuller description of these two most important stages.

Imago.-Elongate oval, piceous black, feebly shining, sparsely clothed with whitish hairs, antennæ, tips of femora, tibiæ, tarsi, and usually the apical margins of elytra red. dish brown. Head finely and very densely punctate above, front finely longitudinally aciculate, more densely hairy, remainder of head nearly glabrous, beneath strongly transversally striate. Thorax sparsely hairy, disk glabrous; more coarsely punctate, less densely on the disk, the punctures more or less elongated and confluent into longitudinal strix. Elytra longer than thorax, narrower behind, tips serrate, separately rounded, surface striate, striæ with close-set punctures as coarse as those of the thorax, intervals wide, with a single row of equally coarse and close-set punctures bearing at intervals conspicuous, erect, whitish bristles; surface also more or less obliquely wrinkled, espécially near the sides and suture; humeral callosities feebly wrinkled. Surface beneath and legs finely alutaceous, densely and very coarsely punctate; thorax and legs sparsely hairy, disk of prosternum nearly glabrous; abdomen compressed at base, less coarsely punctate, clothed with erect bristles like those on elytra; declivity almost plane, not margined, rising regularly from near base to the apex; last segment concave near posterior margin. Length $2-21 / 2 \mathrm{~mm}$.

Larva._Oblong, cylindrical, thicker anteriorly, feebly shining, finely gran ulate, or rugose, whitish, head above and at the sutures below, and palpi, brownish ferruginous, clypeus paler, mandibles black. Head small, clypeus distinct, feebly emarginate in front, anterior and posterior margins nearly parallel, labrum brownish dusky, semicircular, bear. 



\section{EXPLANATION OF PLATE.}

Fig. I. Larva of Scolytus rugulosus, enlarged twenty-two diameters. Fig. 2. Pupa, side view, enlarged twenty diameters.

Fig. 3. Beetle, enlarged twenty diameters.

Fig. 4. Pupa, dorsal view, enlarged twenty diameters.

Fig. 5. Chiropachys colon, Linn., parasite of larva, enlarged eight diameters.

Fig. 6. Small branch of peach, showing perforations of bark; natural size.

Fig. 7. Small branch of plum, with bark removed, showing breed. ing chamber and tunnels in sap wood made by larva; natural size.

Fig. 8. Perforations of bark of large branch of plum tree; natural size.

Fig. 9. Denuded branch, showing breeding chambers, larval channels, and pupal chambęrs; natural size.

Figs. I, 2, 3, 4, 6, 7, and 8 are original drawings, made by Mr. A. M. Westergren; and Figs. 5 and 9 are from unpublished cuts loaned. by Dr. C. V. Riley. 


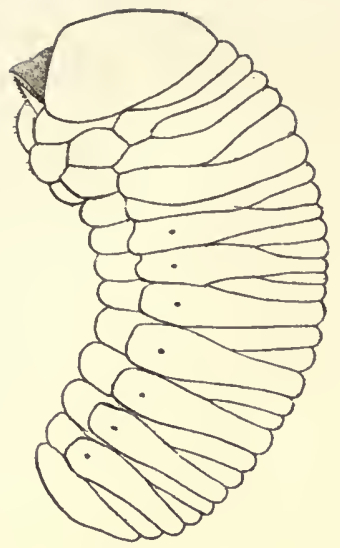

Fig. 1.

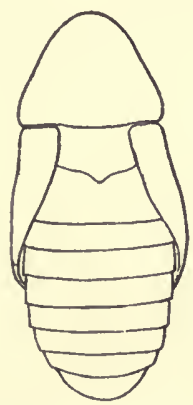

Eig. 4.

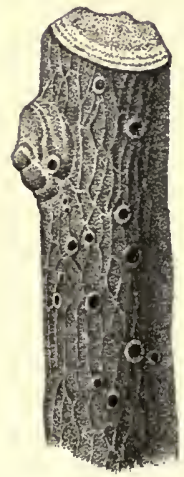

Fig. 6.

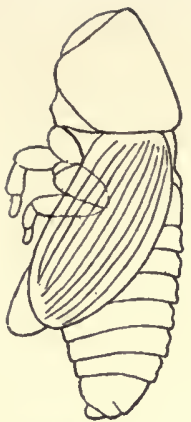

Fig. 2.

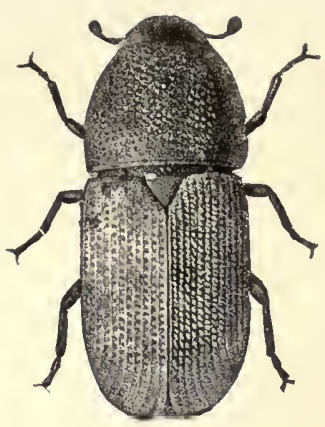

Fig. 3.

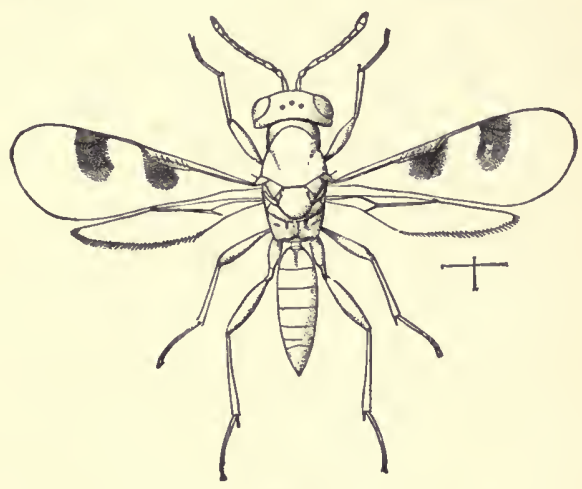

Fig. 5 .

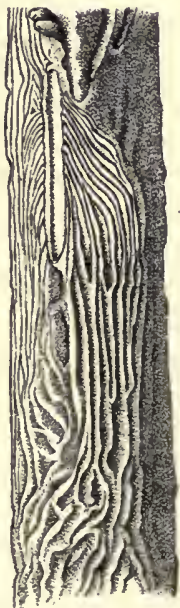

Fig. $\%$

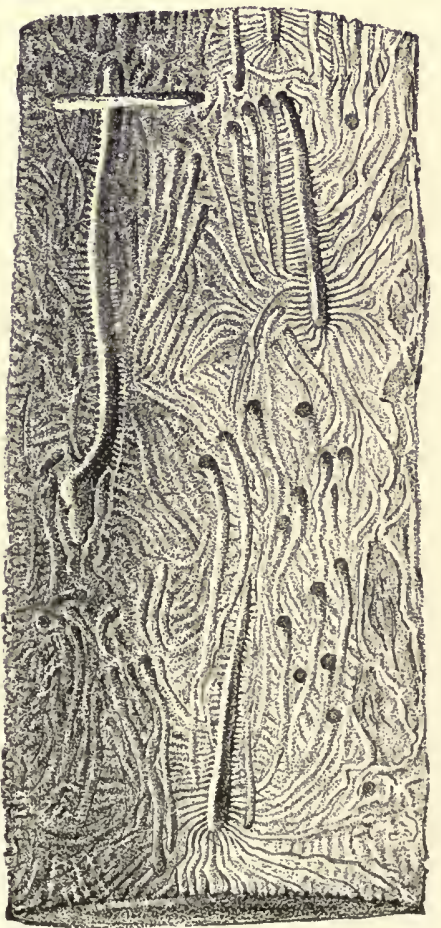

Fig. 9.

Fig. 8 

ing on the anterior margin three to five punctiform impressions, and a few satæ; mandi. bles smooth, rather blunt; palpi biarticulate, the basal joint paler, short and thick, the second brownish, more slender, antennæ two-jointed, minute, situated near the base of the mandibles; just above this a puncture which seems to contain a single minute ocellus. Tho. racie segments somewhat thicker than the abdomen, more densely.granulate and subopaque, the cervical shield with the posterior margin deeply notched on each side, a densely granulate and opaque anterior and posterior border and median line, the latter sulcate and narrowed in front, and lateral lines extending forward each side from the notches in the posterior margin, but becoming obsolete before attaining the anterior border, the remaining spaces shining and but feebly rugose; following segments finely wrinkled transversely, and granulate. Body posteriorly subtruncate, anal segment quadrate, densely granulate, and opaque, the anal aperture in the form of an X. Spiracles faintly darker than ground color, surrounded by concentric wrinkles. I ength $2-2 \mathrm{t} / 2 \mathrm{~mm}$.

\section{Life History and Remedies.}

The facts at hand, when all combined, are not sufficient to settle positively even the general features of the life history of this insect, but leave in doubt, indeed, the number of broods. Schmidberger's account above referred to, the only one based on continuous observations throughout the year, would make it single-brooded in the latitude of Vienna; but his infested apple twigs were kept the whole year in the house, and the transformations are quite as likely to have been retarded in summer by this treatment as to have been hastened in winter. It may be, consequently, that his beetles, which emerged in February would have come out the preceding autumn in time to lay their eggs for another generation if the tree in which they were bred had been exposed to the open sun. This matter is not of immediate practical importance however, as all direct observations in Europe and America show that the insect passes the winter only as a larva under the bark, and that these hibernating larvæ transform and escape as adults from early spring to summer, beginning to emerge as early as the last of March, and laying their eggs without delay. Eggs are certainly laid in the fall (September), and the beetles then perish in our latitude. The larval hibernation in the tree is the vulnerable point in the biography of this insect, and suggests at once the most certain and simple remedy; viz., the destruction by fire, in winter, of the trees or parts of trees containing them.

While it can hardly be said at present that it would be wise to destroy every tree, root and branch, which contain the insects in any number, its certainly is best that all trees badly infested should be cut up and burned during the winter months, and that punctured twigs and branches of those less severely attacked should be cut away and similarly destroyed. As the beetles may begin to emerge in March, this procedure should not be too long delayed. It is now scarcely possible, however, to completely exterminate this insect in Illinois by any measures which may be reasonably taken at the present time. It is too wide-spread, occurs in too great a variety of fruits, quite possibly even in those growing wild in woodlands, and its life history is too imperfectly known to make advisable the drastic measures which an effort at extermination would require. Especially 
I judge that legal compulsion-only to be used as a last resort-should at least be delayed until all the facts are learned, and until all reasonable measures have been tested; including a thorough-going co-operation among fruit-growers in southern Illinois. An attempt at extermination wo imean the absolute destruction of every tree showing even the least attack; and if later investigation should make known some less expensive method, or if a study of the prevalence of parasitism should give us ground to expect a natural limitation of the injury, no such destruction could be justified by the event. The investigations of the next two years will doubtless clear up uncertainties, and enable fruit-growing communities to act wisely and effectively. There is a possibility that thorough treatment of the trees with some poison spray-especially if an adhesive substance is mixed with it-at the time of year when these beetles are making their way into the bark, would have the effect completely to arrest this injury at the same time that it should protect the trees against the cankerworm and many other destructive species. Even the application of soap and soda poisoned with arsenic, now used against ordinary borers, if applied to the larger branches as well as the trunk, might be found to check sufficiently the mischief done by this bark beetle.

The suggestion made by Taschenberg is also worthy of note, namely, that since only the less vigorous trees are successfully attacked-the more thrifty ones pouring out such floods of sap when pierced as either to drive away the beetles or to prevent the development of the young-it is possible that trees already infested to some small extent may be sustained by care and fertilization. Probably the best kept orchards and most vigorous trees will be least likely to suffer from this borer.

\section{S. A. Forbes, Ph. D., Consulting Entomologist.}

\section{EXPERIMENTS WITH GRASS SEEDS, AND WITH GRASSES ANI) CLOVERS.}

In this article the following experiments are reported:

93. Grass Seeds, Tests of Vitality.

16. Grasses and Clovers, Comparison of Varieties.

19. Grasses and Clovers, Tests of Varieties and Mixtures.

86. Effect of Fertilizers on Kentucky Blue Grass Pasture.

\section{Experiment No.93. Grass Seeds, Test of Vitality.}

The tests made in this experiment show that very much of the Kentucky blue grass seed sold in this country has little vitality. Of 18 sam. ples obtained from 17 seedsmen in different parts of the country, an 
average of less than $2 \mathrm{I}$ per cent. of the seed sprouted in soil in the open air; 35.2 being the highest per cent. in any one sample. Under like conditions 48.3 per cent. of seed gathered on the Station grounds sprouted. In four other trials of seed harvested on the Station grounds from 7 1.6. to 80.1 per cent. sprouted. Repeated tests indicate that the Geneva apparatus is not satisfactory in teșting Kentucky blue grass seed, although trustworthy and convenient in testing many kinds of seeds. The tests also indicate that much of the timothy seed sold has a fair degree of vitality. Of 16 samples obtained from as many seedsmen, an average of 76 per cent. sprouted. In but one case did the per cent. sprouting fall below 50; in six it was 91 or more.

In the summer of 1889 , samples of Kentucky blue grass, red top, and timothy seed were obtained from each of $I 7$ prominent seedsmen of this country. Duplicate samples of these seeds, with a sample of very ripe Kentucky blue grass seed gathered on the Station grounds, were tested in the Geneva apparatus, the test beginning July 23 and closing August 31 , 1889 , the average temperature was $68.7^{\circ} \mathrm{F}$. with a range of ten degrees, from $63.5^{\circ}$ to $73.5^{\circ} \mathrm{F}$.

The following table shows the percentages of the seed of each kind which sprouted.

Table Showing Percentages growing of Seed of Kentucky Blue Grass, Red Top, and Timothy tested in Geneva Apparatus.

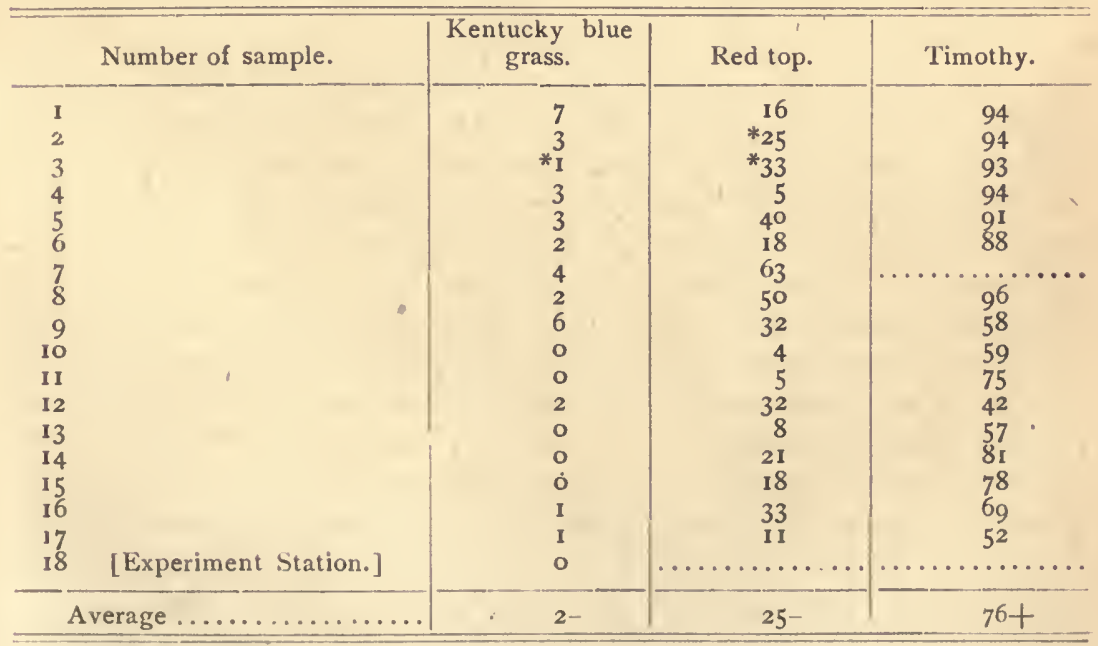

*Two samples.

It will be seen from this table that less than 2 per cent. of the blue grass, 25 per cent. of the red top, and a little more than 76 per cent. of the timothy sprouted. The maximum per cents. in each were 7,63 , and 96, respectively.

In all, 27 samples of Kentucky blue grass seed were tested in the Geneva apparatus, of which less than 2 per cent. sprouted; 7 per cent. in 
two cases was the maximum. In six tests of Kentucky blue grass and red top made at other Stations, I0.5 per cent. of the blue grass sprouted and of red top an average of 56 per cent. sprouted. The largest per cent. of Kentucky blue grass sprouting was 17 and the smallest 5 ; of red top the largest was $9^{2}$ and the smallest 20 .

The results of these tests led to the suggestion that while the Geneva apparatus (an arrangement for sprouting seeds between folds of cotton flannel) has been shown repeatedly to be admirably adapted to the sprouting and testing of many seeds, it, possibly, was in some way not suited to the sprouting of Kentucky blue grass seed.*

In order to test the vitality of the seed in the soil a mixture of pot-1 ting soil and sand was heated in an iron kettle for two hours to kill any seeds that might be present. The temperature of the soil at two to three inches from the top was $95^{\circ}$ to $98^{\circ} \mathrm{C}$. $\left(203^{\circ}\right.$ to $208^{\circ} \mathrm{F}$.) As the soil was stirred from time to time, probably all of it was subject to a somewhat higher heat. In all these tests check boxes were left without any seed sown, and no plants grew in the soil thus heated.

March I3, I4, I 890, boxes averaging about 250 square inches and three inches deep were about half filled with this soil. The soil was moistened with water and a gram of each of the samples of Kentucky blue grass seed already tested in the Geneva apparatus as given above, was sown in separate boxes and the seed covered with from one-fourth to one-half an inch of sand. The boxes were placed under the bench in the greenhouse.

Another set of boxes of soil was similarly sown, except that the seed was covered with soil instead of sand. These boxes were placed on the ground in the open air, in the shade of a row of evergreen trees, and covered with cheese cloth to prevent other seeds from blowing into the boxes.

The seeds sprouting in these boxes were counted and removed from

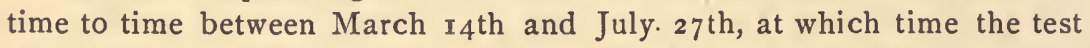
was concluded. The number of seeds in one gram taken from each of four distinct samples of commercial Kentucky blue grass seed was counted and found to be $4,7 \mathrm{rr}, 4,807,4,9 \mathrm{ro}$, and 4,797 or an average of about 4,800 to a gram, and this number was taken as a basis in calculating the per cent. which sprouted.

48 per cent. of the samples gathered upon the Station ground grew in soil in the open air and 57 per cent. in soil in the greenhouse. Of the I 8 samples of seed obtained from 17 seedsmen less than $2 \mathrm{I}$ per cent. sprouted in the open air and a little more than $\mathbf{2} 2$ per cent. in the greenhouse. The greenhouse proved unsatisfactory as a place to test the seeds. The heat and moisture sprouted the seeds well enough, doubtless, but caused them also, in greenhouse parlance, "to damp off." Some boxes evidently "damped off" worse than others on account of receiving more water. The best place as yet found to test this seed is in soil in the open air under the normal conditions of heat and $m$ oisture.

\footnotetext{
*A report of this work was made by Mr. Hunt in Agricultural Science for Jan. I893.
} 
Table Showing Number and Percentage of Kentucky Blue Grass Seeds

Sprouting when sown in SoIt, in the open Air and in the Greenhouse.

\begin{tabular}{|c|c|c|c|c|c|}
\hline & \multirow{2}{*}{ Number of sample. } & \multicolumn{2}{|c|}{$\begin{array}{l}\text { Number of seeds sprouted of } \\
\text { one gram sown. }\end{array}$} & \multicolumn{2}{|c|}{$\begin{array}{c}\text { Per cent. of seeds germinat } \\
\text { ing. }\end{array}$} \\
\hline & & Open air. & Greenhouse. & Open air. & Greenhouse. \\
\hline $\mathbf{I}$ & & 776 & 490 & I6. I & 10.2 \\
\hline 2 & & 1,689 & 964 & 35.2 & 20.I \\
\hline $3 a$ & & 1,032 & 537 & 21.5 & II. 2 \\
\hline $3 \mathrm{~b}$ & & 1,636 & $93 \mathbf{I}$ & 34. I & 19.4 \\
\hline 4 & & 1,429 & I,099 & 29.8 & 22.9 \\
\hline 5 & & $\mathbf{I}, 348$ & 762 & 28.1 & 159 \\
\hline 6 & & 674 & 735 & 14 & 15.3 \\
\hline 7 & & 484 & 396 & I0. I & 8.3 \\
\hline 8 & & 1,320 & 1,090 & $27 \cdot 5$ & 22.7 \\
\hline 9 & & I, 105 & 832 & 23 & $17 \cdot 3$ \\
\hline 10 & & $79 \mathrm{I}$ & $35 \mathrm{I}$ & I6.5 & $7 \cdot 3$ \\
\hline I I & & $\mathrm{I}, \mathrm{I} 48$ & 335 & 23.9 & 7 \\
\hline 12 & & 913 & 696 & 19 & 14.5 \\
\hline $\mathbf{I}_{3}$ & & 1,263 & 255 & 26.3 & $5 \cdot 3$ \\
\hline 14 & & 368 & 121 & 7.7 & 2.5 \\
\hline 15 & & 813 & $34 \mathrm{I}$ & 16.9 & 7.1 \\
\hline 16 & & 798 & 291 & 16.6 & 6.1 \\
\hline 17 & & 1,304 & 586 & 27.1 & 12.2 \\
\hline 18 & [Experiment Station.] & 2,316 & 2,750 & 48.3 & 57.2 \\
\hline
\end{tabular}

The first tests made upon the vitality of Kentucky blue grass led to a correspondence with all the seedsmen whose seed was tested, and to some consultations. It was stated by seedsmen that it was the practice to cut or strip Kentucky blue grass for seed when it was still quite green, as more and cleaner seed could be obtained in this way; and that in curing or drying, it often heated and spoiled.

It was decided to attempt to test this matter. June $13,14,1890,60$ lb. of Kentucky blue grass seed was stripped with the hand instrument ordinarily used for this purpose. The seed was green but probably not in so early a stage as would have been desirable. $20 \mathrm{lb}$. was spread on a floor in a dry room; $20 \mathrm{lb}$. on a canvas in a damp cellar; and $20 \mathrm{lb}$. was left in a grain sack in a dry room. June 28 th to July $2 \mathrm{~d}, \mathrm{r}_{5} \mathrm{lb}$. of ripe seed was stripped and spread in a dry room. After remaining in this condition for about 3 months the seed was passed thrice through a seive having eight meshes to the linear inch. No exact test was made, but the seed appeared nearly, if not quite, as clean as commercial seed, with the exception of the seed gathered ripe which contained more broken pieces of the stems and had soft cobwebby hairs adhering to the seed. A gram of each sample was counted and the number of seeds ascertained, as given in the table below. It will be seen by comparing that there was a less number of seeds in a gram of these samples than in commercial seed. This may indicate that the seed naturally grows larger in this locality than where the commercial seed comes from, or that commercial. seed is usually gathered when still greener than the greenest of these samples, in which case it would be smaller.

Sept. 20, 1890, duplicate boxes of soil prepared as heretofore described, were sown with a gram of each of the four samples of blue grass 
seed and placed in the open air to grow. The number of seeds growing in each box was counted and the plants removed from time to time.

The following table gives the results obtained up to November 27 , ז 890 .

TABLE Showing the Vitality of Kentucky Blue Grass Seed cured in different WAYS.

\begin{tabular}{|c|c|c|c|c|c|}
\hline \multirow{2}{*}{ Condition of gathering and keeping the seed. } & \multicolumn{3}{|c|}{$\begin{array}{l}\text { Number of seeds } \\
\text { sprouted in a gram. }\end{array}$} & \multirow{2}{*}{$\begin{array}{l}\text { No. of } \\
\text { seedsin a } \\
\text { gram as } \\
\text { sown. }\end{array}$} & \multirow{2}{*}{$\begin{array}{l}\text { Per cent. } \\
\text { of seeds } \\
\text { sprout- } \\
\text { ing. }\end{array}$} \\
\hline & a. & b. & $\begin{array}{c}\text { Aver. } \\
\text { age. }\end{array}$ & & \\
\hline $\begin{array}{l}\text { Gathered green and dried on floor in a dry room } \\
\text { Gathered green and dried in cellar } \ldots \ldots \ldots \ldots \ldots \\
\text { Gathered green and dried in grain sack......... } \\
\text { Gathered ripe and dried on floor in a dry room.. }\end{array}$ & $\begin{array}{l}2,994 \\
2,976 \\
3,040 \\
3,069\end{array}$ & $\begin{array}{l}2,737 \\
2,768 \\
2,970 \\
2,851\end{array}$ & $\begin{array}{l}2,866 \\
2,872 \\
3,005 \\
2,960\end{array}$ & $\begin{array}{l}3,954 \\
4,014 \\
4,127 \\
3,695\end{array}$ & $\begin{array}{l}72.5 \\
71.6 \\
72.8 \\
80.1\end{array}$ \\
\hline
\end{tabular}

The per cent. of seeds sprouting in the three samples gathered green was practically alike, being a little more than 72 per cent.; while that of the ripe seed, on the basis of the number of seeds found in a gram, was somewhat higher, being 80 per cent. The seed gathered green and preserved in any of the three ways, two of which would be presumably unfavorable, had more than three times the vitality of $\mathrm{r} 8$ samples of blue grass seed received from 17 firms, and twice as great as any one of the samples so obtained.

Three points are still to be determined: the vitality if gathered still greener; the vitality during a series of years; and the length of time the seed will retain its vitality. But the tests are sufficient to indicate that a better grade of Kentucky blue grass seed may fairly be expected of the seedsmen of this country.

\section{Experiment No. I6. Grasses and Clovers, Comparison of Varieties.}

Several varieties of grasses and clovers have been grown on small plats, usually one-tenth of an acre plats, for the purpose of observing their growth, time of ripening, and endurance in this soil and climate.

Timothy and medium red clover, the staple hay crops of the state, and Kentucky blue grass and white clover, staple pasture crops, have been grown to serve as a basis for comparison.

Red top, Agrostis vulgaris, does not seem especially adapted to the prairie soil of this locality. The seed is apt to be poor and the plants do not take possession of the soil as quickly as do those of timothy, but it eventually makes a more compact sod. The hay is generally regarded with disfavor by buyers. From a tenth acre plat, red top yielded at the rate of $\mathrm{r} .8$ tons per acre, while an adjacent plat of timothy yielded r.7 tons per acre.

Orchard grass, Dactylis glomerata, grows to a height of four feet on this soil. It grows in bunches or tussocks and produces an abundance of leaves early in the season, while the seed culms are rather sparingly pro- 
duced, the result being a light yield, as will be seen from Experiment No. 19. It is in condition to cut in June, about the same time as medium red clover, and ripens about July rst. It is a special characteristic of this crop that it starts to grow sooner after being cut than any other grass grown for hay. Analyses made at the Station [Bulletin No. 5, p. I63.] indicate a high percentage of albuminoids as compared with timothy. Thirty-five pounds of seed are required per acre. Sowing a less amount reduced the yield. A limited experience does not especially commend it for pasturage.

Meadow fescue, Festuca pratensis, seems adapted to this soil. It starts early in the spring-as early as Kentucky blue grass-and makes a compact, leafy sod indicating desirable pasturage. Its palatability has not been tested here. It throws up seed culms rather sparingly. They grew 40 inches high in 1890 . One-tenth of an acre yielded at the rate 2,830 lb. of water-free substance per acre, or $3,775 \mathrm{lb}$. of field-cured hay containing 25 per cent. of water. As a hay crop it seems superior to Kentucky blue grass but not equal to timothy. It is ready to cut about the middle of June.

Taller fescue, Festuca elatior, as grown here was but two inches taller than meadow fescue and was otherwise very much like it. The yield of water-free substance from one-tenth of an acre was at the rate of $2,35^{\circ}$ lb. per acre, and the weight of field-cured hay containing 25 per cent. of water was $3, \mathrm{x} 35 \mathrm{lb}$. per acre.

Sheep's fescue, Festuca ovina, and hard fescue, Festuca duriuscula, are both on this soil small, low growing species with spreading culms. The pasturage does not seem so desirable as that from several other species of grasses, and the yield of hay was not sufficient to make it worth while to cut the plats.

Tall meadow oat grass, Arrhenatherum avenaceum, is the earliest grass to start in the spring and the latest growing grass of any that has been tried here. It grew to an average height of 62 in. in 1890 and the plat was densely covered with culms. The culms or seed stalks are somewhat coarser than those of timothy and appear woody. The yield of waterfree substance on a tenth of an acre was at the rate of 4,1 ro lb. per acre, or $5,480 \mathrm{lb}$. of field-cured hay, containing 25 per cent. of moisture. This is a very satisfactory yield, and if the hay proves valuable it will be an important addition to our hay crops.

Both the Italian rye grass, Lolium Italicum, and the perennial rye grass, Lolium perenne, made a good growth and produced hay the same season the seed was sown. The culms of the Italian rye grass grew $3 \mathrm{ft}$. high and those of the perennial rye grass about $2 \mathrm{ft}$. high. In both cases the stand was good and the growth abundant. The next season there was very little if any stand where the Italian rye grass was sown and only about one-third of a stand where the perennial rye grass was sown.

Roughed stalked meadow grass, Poa trivialis, and wood meadow grass, Poa nemoralis, formed a fair sod; but neither for pasture nor for hay was 
the growth equal to that of the Kentucky blue grass, Poa pratensis, although with the seed sown, all of which was of low vitality, the first two produced a sod quicker. The culms or seed stalks of each were 24 to 26 in. high.

Sweet vernal grass, Anthoxanthum nderatum, has been sown three seasons on a tenth of an acre and in no case has a stand resulted. Four distinct samples have been tested in the Geneva apparatus, and 7, 9, I7, and 20 per cent. respectively, sprouted. The few plants that have grown indicate that it is of little or no value on this soil. The plants were in bloom about June $15^{\text {th }}$ and the culms were 10 to $12 \mathrm{in}$. high.

Meadow foxtail, Alopecurus pratensis, has been sown three seasons without securing a good stand. The seeding of the spring of 1890 , the best obtained, is possibly one-half of a stand. Three distinct samples have been tested in the Geneva apparatus, and $\mathrm{II}, 73$, and 35 per cent. respectively, sprouted. The plant has a superficial resemblance to timothy, although apparently inferior to it.

Mammoth red clover, Trifolium medium, is distinguished from medium red clover, Trifolium pratense, by its larger and coarser growth and by the fact that it usually yields but one crop in a season; otherwise the two are much alike. It is ready to cut about the same time as timothy, or three to five weeks later than the medium red clover. Where timothy and medium red clover are sown together and harvested at the proper time for the clover, the yield of timothy is much less than if allowed to become more mature, as is shown by experiments made at this Station upon the effect of ripeness upon the yield of grasses and clovers. [Bulletin No. 5.] As shown in Experiment No. I9, where sown with timothy, mammoth clover, during two years, gave a larger yield from two cuttings than did medium clover and timothy with three cuttings. On account of the drouth the second crop of medium clover was not harvested the second season. Had the season been favorable, doubtless four crops of medium clover and timothy would have yielded more than two crops of mammoth clover and timothy. The fact that mammoth clover may be cut in July instead of June makes it more readily cured and less liable to damage from rains while curing. On rich lands it grows rather coarse and the quality of the hay is not considered so good by many. It is not at all likely that it will displace medium clover in any great measure; but, after considerable practical experience with this crop it is believed that it would prove a profitable and desirable crop in many parts of the state.

Alfalfa, Medicago sativa, does not seem well adapted to this soil. A fairly good stand was secured on a tenth of an acre plat. When in bloom, July 1 oth to $15^{\text {th }}$ the season the seed was sown, the plants were $18 \mathrm{in}$. high. The second season the stand was fair, but the plants did not seem to take possession of the ground like most other hay crops. The plat became much more weedy than the other plats sown to clovers and grasses. Compared to medium red clover, the growth was light. In 
other trials a satisfactory stand was not secured. When well established the plants appear hardy.

Alsike clover, Irifolium hybridum, is a finer, smaller clover than medium red clover, with blossoms in small reddish white heads. In growth it is about half way between medium red clover and white clover, Trifolium repens. It does not seem enduring on this soil and the results in Experiment No. Io indicate that on this soil it is by no means equal as a hay crop to medium red clover.

Crimson trefoil, Trifolium incarnatum, grows about 12 in. high on this soil, and was cut May 20, I890, when it was in full bloom while occasionally a head had some seed. The heads are a small cluster of yellow blossoms. The leaves are small and the stalks fine. It is too small for a hay crop, and is open to the objection of maturing the first crop too early; for so early in the season it is almost impossible to get grass or clover to dry in a suitable length of time. This clover was handled six times during six days, and at the end of that time the stems were still green although wilted. The yield of hay in this condition was at the rate of $2,370 \mathrm{lb}$. per acre. The plant seems enduring and may prove valuable for pasturage.

\section{Experiment No. I0. Grasses and Clovers, Test of Varieties and Mixtures.}

Nine two-acre plats of grasses, clovers, and mixtures were sown in I 888 with a view to testing varieties and mixtures on a considerable area, and also to obtain sufficient hay of the several varieties and their mixtures to use for feeding tests. The burning of the experiment barn has prevented making the feeding tests.

The tract used was fall-plowed, sown to oats April 6, 7, 1888, and with grass and clover seeds, as shown in the table, April I2th to r 4 th.

The plats were mown at the following dates :

TABLE Showing when Grasses and Clovers were cut, 1889, i89o.

\begin{tabular}{|c|c|c|c|c|}
\hline \multirow{2}{*}{$\stackrel{\frac{T}{m}}{\rightleftarrows}$} & \multirow{2}{*}{ Crop grown. } & \multicolumn{2}{|c|}{ I88g. } & \multirow{2}{*}{$\begin{array}{l}1890 . \\
\text { Time of } \\
\text { cutting. }\end{array}$} \\
\hline & & $\begin{array}{l}\text { Time of } \\
\text { cutting. }\end{array}$ & $\begin{array}{l}\text { Time of } \\
\text { cutting. }\end{array}$ & \\
\hline \begin{tabular}{l|l} 
& \\
2 & \\
3 & \\
4 & \\
5 & \\
6 & \\
7 & \\
8 & \\
9
\end{tabular} & 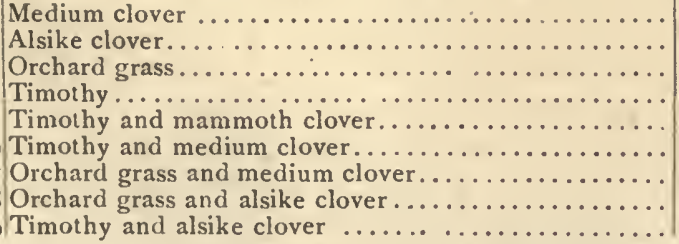 & $\begin{array}{l}\text { June } 13 . \\
\text { June } 13 . \\
\text { June } 20 . \\
\text { July } 22 . \\
\text { July } 22 . \\
\text { June } 20 . \\
\text { June } 20 . \\
\text { June } 22 . \\
\text { June } 22 .\end{array}$ & $\begin{array}{l}\text { August 17. } \\
\text { August 12. } \\
\text { August 19. } \\
\cdots \\
\text { August i9. } \\
\text { August I9 } \\
\text { August I4. } \\
\text { August } 14\end{array}$ & $\begin{array}{l}\text { June } 19 . \\
\text { Jun: } 19 . \\
\text { June } 18 . \\
\text { July } 11 . \\
\text { July } 10 . \\
\text { June } 26 . \\
\text { June } 18 . \\
\text { June } 18 . \\
\text { July } 10 .\end{array}$ \\
\hline
\end{tabular}

The time of cutting, as well as the field notes, indicate that the alsike clover ripens earlier than medium red clover; that medium red clover and orchard grass ripen about the same time; that timothy ripens from 
three to five weeks later than medium red clover and about the same time as mammoth red clover.

Where timothy and medium red clover were sown together, the first crop the second year was from two-thirds to three-fourths clover and from one-fourth to one-third timothy; and the third year from seeding, second year of cropping, the crop was about two-thirds clover and onethird timothy.

Where timothy and mammoth red clover were sown together, the first crop was almost entirely clover, and the crop the second season was probably about one-third to one-half timothy. Where timothy and alsike clover were sown together, the first crop was from two-thirds to three-fourths alsike clover, and the crop the next year was practically entirely timothy.

Where orchard grass and medium red clover were sown together, the first crop was about one-half clover, and the stand was poor as compared to the clover sown with timothy. The next year there was more clover than orchard grass, and the orchard grass was not so good a stand as where sown with alsike clover.

Where orchard grass was sown with alsike clover the first crop was at least pne-half orchard grass, and the stand of alsike clover was not so good as where sown with timothy. The next year the crop was almost entirely orchard grass.

In no place was the alsike clover enduring. Orchard grass or timothy when sown with it developed more fully than when sown with medium red clover. Medium red clover developed much more fully when sown with timothy than when sown with orchard grass.

When each crop was harvested samples were taken of the hay of each plat and the per cent. of water in the hay was determined by the chemist of the Station.

Table Showing Pounds of Seed sown on Grass and Clover Plats; also the Yield of Water-free Substance and Field-cured Hay in r889, i89o.

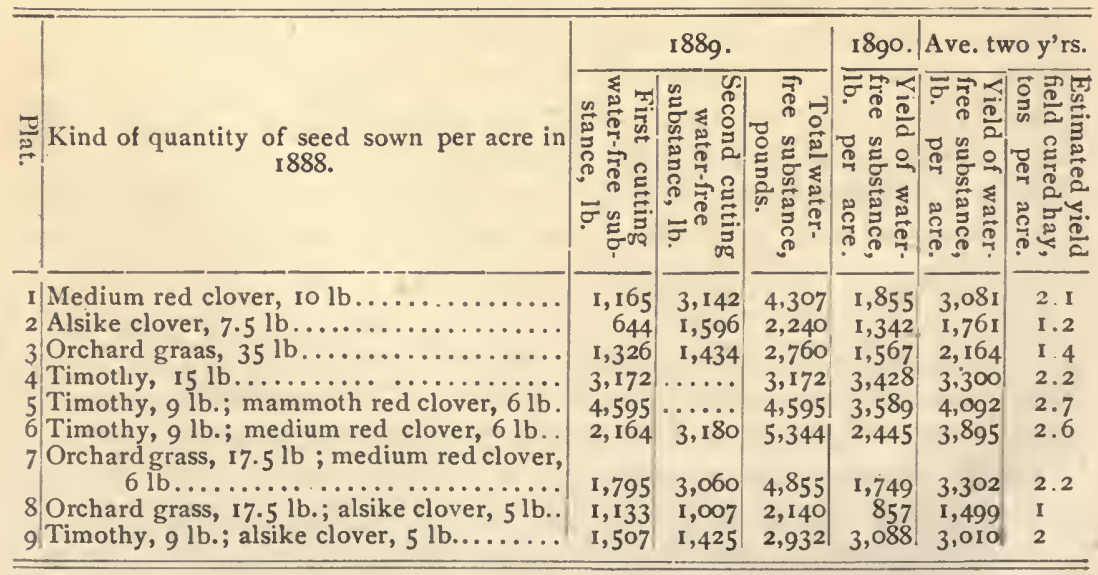


From the weight of hay and the per cent. of water found in the samples the weight of the water-free substance from each plat was calculated as given in the table on the opposite page; that is, the weight of hay after all the water has been expelled by drying at about the boiling point of water. In the last column the tons per acre of field-cured hay is calculated by assuming that the hay when hauled from the field would contain an average of 25 per cent. of moisture, which is approximately correct [Bulle$\operatorname{tin} N 0.5, p . I 63]$, although there is usually a larger per cent. of water in clover as it is put into stack or mow than in the grasses. The moisture in field-cured hays may vary from 18 to 35 or more per cent.

The largest yield of hay, 2.7 tons per acre, was from timothy and mammoth clover sown together, which during the two years gave a little larger yield at two cuttings than timothy and medium red clover at three cuttings.

Timothy gave the largest yield, 2.2 tons per acre, of any single plant, giving a little more at two cuttings than did medium red clover at three.

Orchard grass gave a little larger yield than alsike clover; but both yielded very much less either when sown alone or sown together than did timothy or red clover. They yielded less when sown together than when sown alone. Orchard grass and red clover, and timothy and alsike clover gave poorer yields than timothy and red clover. The test was made under favorable circumstances, and the areas-2 acres for each plat-were sufficient to suggest that neither alsike clover nor orchard grass will probably fill any larger place than now in practical farming on the prairie soils of central Illinois.

\section{Experment No. 86. Effect of Fertilizers on Kentucky Blue Grass Pasture.}

With a view to determining whether old pastures might be profitably improved by their application, stable manure and commercial fertilizers of several kinds were applied in 1889 and in 1890 to a Kentucky blue grass pasture of at least 15 years standing.

The land used was a rather elevated portion of a forty-acre pasture, and consisted of eleven quarter of an acre plats, each $4 \mathrm{x}$ ro rods.

It did not seem practicable at the time to determine by constant cropping the yield of pasturage from the several plats. The yield of hay, therefore, was ascertained. As in this locality,'at least, blue grass hay from the most fertile land would not be profitable usually, the absolute increase of hay due to the fertilizers can not be taken as indicating the value of the fertilizers, but rather the proportion of increase. That is to say, if we get an increase of 800 pounds of hay per acre and that is an increase of one-half, the value of the increase is one-half the rental value of the acre of pasture, rather than the selling price of the 800 pounds of hay. Even this method of getting at the value of the increase rests upon the assumption that the pasturage would be increased in the same proportion as the increase in the yield of hay, an assumption which has not yet been verified by experiment. 
The use of horse manure of rather poor quality at the rate of 12 loads per acre increased the yield of hay in two years, in one instance 73 per cent. and in another instance 45 per cent. The only difference in treatment in the two plats was that in the former the first application was made in the fall previous while in the latter both applications were made in the spring. The fact, however, that the greatest difference in increase in these two plats was in the second season, would indicate that the difference was not due to the time of applying the manure.

If pasture land rented for $\$ 4$ per acre, it would cost $\$ 2.9^{2}$ to rent a piece of land that would yield pasture equivalent to the 73 per cent. increase, and $\$$ r.80 to rent pasture equivalent to the 45 per cent. increase. Whether or not there is any direct profit, each farmer may decide for himself. That there will be an increased yield from the manured plats in subsequent years is to be expected, and further experiment will determine. A considerable experience upon the University farms in topdressing pastures does not seem to indicate any material decrease in the palatability of the grass.

The use of cattle tankage and superphosphate at the rate of 500 pounds per acre increased the yield about one-fourth. Pasturage equivalent to this increase might be rented for $\$ \mathrm{I}$, if land rents at $\$ 4$ per acre. The cost of these applications was about $\$ 5$ per acre. The future effect of the fertilizers can be determined by longer experiments only.

Table Showing Effect of Fertilizers on Kentucky Blue Grass Pasture.

\begin{tabular}{|c|c|c|c|c|c|c|c|}
\hline 常 & Kind of fertilizer both seasons. & 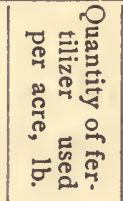 & 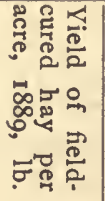 & 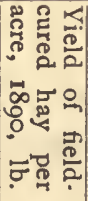 & 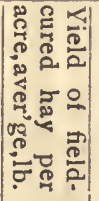 & 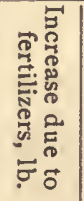 & 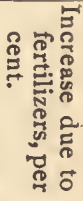 \\
\hline I & Horse manure ${ }^{1}$. & 12 loads. & 2,340 & 3,180 & 2,760 & $\mathbf{I}, \mathbf{1 6 5}$ & 73 \\
\hline 2 & None & $\ldots$ & 1,220 & 2,100 & 1,660 & $\cdots \cdots$ & ...... \\
\hline 3 & Catt & $500 \mathrm{lb} .$. & 1,600 & 2,400 & 2,000 & 405 & 25 \\
\hline 4 & phosphate... & $500 \mathrm{lb} .$. & 1,880 & 2,200 & 2,040 & 445 & 27 \\
\hline 5 & $\ldots \ldots \ldots \ldots \ldots$ & $\ldots \ldots$ & 1,080 & 2,040 & 1,560 & $\cdots \cdots$ & $\ldots \ldots$ \\
\hline 6 & $\begin{array}{l}\text { Horse manure } \ldots \ldots \ldots \ldots \ldots \ldots \\
\text { Superphosphate............. }\end{array}$ & $\begin{array}{l}\text { I3 loads. } \\
500 \mathrm{lb} . .\end{array}$ & 2,160 & 2,460 & 2,3 IO & 715 & 45 \\
\hline 7\{ & $\begin{array}{l}\text { Muriate of potash }{ }^{8} \ldots \ldots \ldots \\
\text { Nitrate of soda } . \ldots \ldots \ldots\end{array}$ & $\begin{array}{ll}200 & \mathrm{lb} . \\
200 & \mathrm{lb} .\end{array}$ & 2,280 & 3,060 & 2,670 & 1,075 & 67 \\
\hline 8 & None......... & $\ldots \ldots$ & 720 & $2, \infty 00$ & $\mathbf{1}, 560$ & & \\
\hline 9 & Muria & $200 \mathrm{lb} .$. & 960 & 2,320 & I, $\mathbf{1}, 640$ & 45 & \\
\hline 10 & of sod & 200 lb. . & $\mathbf{I}, 040$ & 2,340 & I, 690 & 95 & \\
\hline 11 & 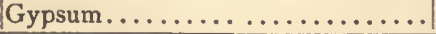 & $5001 \mathrm{~b}$ & 780 & 2,060 & 1,420 & & \\
\hline
\end{tabular}

I. $24,320 \mathrm{lb}$, in 189 o. 2, $21,88 \mathrm{olb}$. in 1890 . 3. Sulphate of potash in 1890 .

Neither potash salts nor nitrate of soda when used singly at the rate of 200 pounds per acre materially increased the yield. Nitrate of soda always gave the grass a greener color. Gypsum at the rate of 500 pounds per acre seemed to have no effect. The use of superphosphate, muriateof potash, and nitrate of soda together increased the yield 67 per cent. Estimated as heretofore, the increase would be worth $\$ 2.68$. The cost of the application was about $\$ 16.00$ per acre. 
Horse manure was:spread on plat I in December, 1888, and again March 15, 1890. March 19, 1889, and March 15, 1890, horse manure was spread on plat 6. March 20, 1889, and March 21,1890 , the commercial fertilizers were spread on the plats as given in the table, except in 1889 the gypsum was not applied until March 30 th.

The grass was mown June 19, 1889, and June 16, 17, 1890. The hay was weighed June 20-22, 1889, and June $21-23,1890$.

The table on the opposite page gives the kinds of fertilizers used each season, the quantity used per acre; the yield of field-cured hay per acre each season, and the average; the increased yield of hay on plats where fertilizers were applied over the average of the three plats not fertilized, and the per cent. of increase of hay due apparently to the use of the given fertilizers.

G. E. Morrow, A. M., Agriculturist.

T. F. Hunt, B. S., Assistant Agriculturist.

\section{USE OF FUNGICIDES UPON THE APPLE, THE POTA'TO, AND THE GRAPE.}

Experiment No. 55 .

The Apple. The corroded, dark-colored spots or patches very frequently seen on apples are the result of a parasitic fungus known to botanists as Fusicladium dendriticum. The disease itself is called"scab." We say the apples are "scabby." It is often a very injurious disease. The apples so affected are unattractive in appearance, are often less in size than they would have been, are misshapen, and do not keep well. Rot sets in at these corroded spots, and the whole fruit soon perishes.

Upon closer observation it may be seen that the central part of the affected spot is covered during the growing season by a dull, dark green, velvety coating, wholly unlike the polished skin of the healthy fruit. Around the margin of the spot there is a narrow whitish band. The geeenish part is producing a dense crop, and the velvety appearance is itself due to the multitudes of spores covering the surface at the time. The white rim is the dead and somewhat upturned edge of the epidermis which is destroyed little by little by the slow-growing fungus. At first the scab is a mere point. From this point the fungus radiates in every direction and the scab grows larger in consequence. Then the varnished natural protection of the inner tissues having been destroyed, the latter are much more subject to other rots.

The same fungus lives upon the green leaves and twigs of the tree, and really does much more serious damage here than by the more con- 
spicuous injury to the fruit. The leaves become more or less distorted, often thickened in places and bulged. Finally these affected parts die outright, leaving the leaf ragged or entirely destroyed.

Trees thus affected in midsummer cannot mature a good crop of fruit, neither can they properly prepare themselves for winter. It will therefore be seen that the disease is really a bad one, and that any method of successfully treating it is of much importance.

The experiment of testing the value of fungicides was begun on apples in 1888 . The apple trees and fruit in the experimental orchard planted in $\mathrm{r} 87_{2}$ had for several years been infested with scab, to such an extent that on many varieties little or no perfect fruit could be found, while none of the varieties were entirely free from the disease. This orchard furnished as good a place as could be desired in which to test fungicides on apple scab. As there was nothing later at hand for a guide, Scribner's report on "Fungus Diseases of the Grape Vine," r886, was followed in the preparation of eau celeste. According to his formula [see page II4] a preparation was made of $\mathrm{I} l \mathrm{lb}$. of copper sulphate (blue vitriol) to ro gallons of water and one pint of commercial ammonia, and it was applied May 24th to one side of each of seven apple trees. The same trees were again sprayed lightly with a weaker solution ( $\mathrm{I}$ lb. to $\mathrm{r}_{5}$ gall. water) May 3rst. The first spraying had injured the leaves very decidedly, so much that two of the trees lost half their leaves within a few weeks. The trees were again sprayed June $25^{\text {th }}$ with eau celeste of the weaker solution, and this time an additional tree was sprayed to see whether the preparation of this strength would burn the leaves and fruit. Examination of this tree a week later showed some damage to the leaves but not enough to make any of them fall.

A solution of sulphate of potassium was made ( $5 \mathrm{oz}$. to ro gallons of water), and four trees were sprayed with it May $24^{\text {th }}$ and 3 rst, and June $25^{\text {th }}$; one tree, May 3 ist and June 25th; and three trees, June $25^{\text {th. }}$ The sulphide of potassium produced no injurious effect that could be seen.

All the trees and varieties of apple that year, whether sprayed or not, were practically free from scab, and the only thing gained was the knowledge that eau celeste of the strength used would injure the apple.

In 1889 , four winesap trees, planted in 1879 , were sprayed on one side with eau celeste, and three other winesap trees on one side with the Bordeaux mixture. [Formula on $p$. 495.] The spraying was done June $5^{\text {th }}$ and $r 7$ th, and July 3 d. The fruit when picked was divided for comparison into scabbed and not scabbed, all those being put in the latter list that were so free from scab as to be uninjured for market. The following table shows comparative results.

Apples from : Whole number. Not scabbed. Scabbed.

sides of trees sprayed with eau celesle..........148

sides of same trees not sprayed ..............133

stdes of trees sprayed with Bordeaux mixture.... 337

sides of same trees not sprayed.............. 52

$\begin{array}{rr}61 & 78 \\ 12 & 121 \\ 72 & 65 \\ 16 & 136\end{array}$


There were not only more good apples in proportion to the whole number on the sprayed sides of the trees, but the apples picked out as not scabbed were larger on the side sprayed than on the other.

In 1890 , six winesap trees were sprayed with a preparation of carbonate of copper. [Formula on p. 495.] Four winesap trees were left unsprayed as checks. The spraying was done May 2 oth and June $x$ th and 26 th. London purple, at the rate of I $\mathrm{lb}$. to I 60 gall. of water, was applied with the fungicide May 20 th. It has been reported that the application of London purple with the fungicides is more likely to damage the foliage than if they are used separately. No damage coming from the spraying was noticed in this case. The apple crop for the season of 1890 was, as all know, almost a complete failure. The six trees sprayed yielded when picked, September 3 oth, $5^{8} \mathrm{lb}$. of apples-less than one bushel; and the trees not sprayed yielded 12.9 pounds of apples-less than $1 / 4$ of a bushel. Even with the very small crop, the effect of spraying was very clearly seen, the apples from the sprayed trees being more nearly free from scab and averaging much larger. Fifty-eight apples from the sprayed trees were equal in weight to roo from the trees not sprayed.

The table below shows results.

\begin{tabular}{|c|c|c|c|c|c|}
\hline & $\begin{array}{l}\text { Wt. apples } \\
\text { produced. }\end{array}$ & $\begin{array}{l}\text { Wt. I } 00 \\
\text { apples. }\end{array}$ & $\begin{array}{l}\text { No. apples } \\
\text { produced. }\end{array}$ & $\begin{array}{l}\text { No. apples } \\
\text { not scabby. }\end{array}$ & $\begin{array}{l}\text { No. apples } \\
\text { scabby. }\end{array}$ \\
\hline & $5^{8} \mathrm{lb}$ & I5. I lb. & $3^{83}$ & II5 & 268 \\
\hline es not sprayed........ & I2.9 lb. & $8.8 \mathrm{lb}$. & 147 & 2 & 145 \\
\hline
\end{tabular}

It seems desirable in this connection to notice the work of others in the same line.

Some work done in 1889 in Wisconsin under the direction of Professor E. S. Goff, Horticulturist of the Wisconsin Experiment Station, gave excellent results with the preparation of carbonate of copper and very favorable results with potassium sulphide, soda hyposulphite, sulphur powder, and liquid sulphur preparation. The carbonate of copper gave so much more favorable results than either of the others that Mr. Goff seems inclined to recommend that alone. The test showed that of the apples sprayed with the carbonate of copper 75 per cent. were entirely free from scab, while of the apples not sprayed 23.3 per cent. only were free from the scab.

In a similar set of experiments made by Professor L. R. Taft, Horticulturist of the Michigan Experiment Station, the best results were obtained from the use of a modified form of eau celeste [Formula on $p .495]$, though results nearly as favorable were obtained from the use of the preparation of carbonate of copper. In Professor Taft's trials 12.5 per cent. only of the apples on the trees not sprayed were free from scab, while on the trees sprayed with the modified eau celeste 68.8 per cent., and on those sprayed with carbonate of copper $\$ 1.2$ per :cent. of the apples were entirely free from scab. 
The Potato. To test fungicides on potatoes a tract of ro rows 80 ft. long was used. This was subdivided so that the plats sprayed each consisted of ro rows $20 \mathrm{ft}$. long. The plats lay adjoining each other and appeared to be as nearly equal at the beginning of the experiment as could be desired. June $23 \mathrm{~d}$ and July 5 th, plat I was sprayed with the Bordeaux mixture, plat 2 with eau celeste, and the third plat with carbonate of copper. At the time of the first spraying the potato vines and leaves were perfectly free from disease but they began to show it within a week, and within three weeks most of the leaves were dead.

The plat sprayed with Bordeaux mixture appeared to remain green longer than the rest, while the plats sprayed with the other two preparations showed no positive results until time of digging when the

Plat sprayed with Bordeaux mixture yielded............... $863 / 4 \mathrm{lb}$.

Plat sprayed with eau celeste yielded .......................

Plat sprayed with carbonate of copper yielded ................ $681 \frac{1}{4} \mathrm{lb}$.

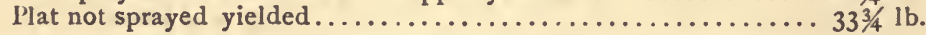

Although the yield in all the plats is small, the difference between the plat not sprayed and those sprayed is very marked.

The Grape. The Black Rot of the grape is by far the worst of the American vine diseases, though these are very numerous. It may be called the rot of the grape berries in most portions of our country. Though it affects both leaf and fruit, it is upon the latter that it is commonly observed. As in the case of the scab of the apple, this, too, is the work of a parasitic fungus (Physalospora Bidwellit), but a widely different species from that previously described. The extreme outer layers only of cells are killed in the apple, but the whole substance of the grape is destroyed. On the green grape berry may be seen at first a minute brown point which rapidly enlarges into a broad brown spot sharply bounded by the healthy green substance of the fruit. Within a few days time the small affected area enlarges until it covers a half or more of the berry, which so far preserves its shape. Soon, however, this affected part shrinks, the skin becomes wrinkled; then the whole berry dries up into an irregularly angular, and comparatively small mass. It usually adheres a long time to the stem with perhaps all the others belonging to the same bunch or cluster. After the skin has become considerably wrinkled, close looking will reveal a dusty, white powder breaking up from minute openings in the shriveled fruit. This dust is made up of spores, eacl exceedingly minute in size but capable of starting the same destruction in a fresh berry. Rains and dews favor the development of the rot, because the spores require water for their germination, when they fall from the wind currents upon the skin of the berries.

On the leaves the fungus is found in small dead spots, distributed over which may be seen with a magnifier little darker colored pustules. From these latter are poured forth the same kind of minute white spores that form the powdery substance on the rotting berries. However, the vine itself does not usually suffer severely. It is the fruit that is mostly affected. 
The shriveled berries at length fall to the ground where they lie during the winter and spring, and in them during this time another kind of spores is formed, which perpetuates the fungus for another year's destruction. The total loss of grapes in our country by this disease amounts to a great proportion on the average of the whole crop. It is exceedingly fortunate that we can attain so much of success in combating it by spraying. Testing fungicides for black rot on the grape was begun in 1888 . The vineyard used for the test is one belonging to the University farm, in which the fruit had several times been badly damaged or nearly destroyed by black rot, though the year before spraying was begun, the fruit had been almost perfect, there being șo little rot that it was not noticed.

The vineyard is on a flat piece of ground, not well drained; it contains about $I / 4$ acres in 14 rows. Four rows were sprayed with sulphide of potassium and four with the strong eau celeste, the same as first used on the apples. The spraying was done May 3 ist, June $25^{\text {th, }}$ and July 9 th. The grape leaves were slightly burned by the application of eau celeste. Some more than half the grapes rotted on all the vines, whether sprayed or not sprayed, and a careful estimate of results the latter part of August, and weighing the fruit when gathered, failed to show any difference that could be attributed to spraying.

During the summer of 1889 , the four rows of grapes referred to above were sprayed with the eau celeste and four others with the Bordeaux mixture. The spraying was done May 20 th, June 5 th and $\mathrm{r} 7 \mathrm{th}$, and July $3^{\mathrm{d}}$. The grapes began rotting by the 5 th of June, and the rot kept spreading, almost without stopping, until the few grapes left were beginning to turn. Many of the vines by that time bore no perfect fruit. The four rows sprayed with the Bordeaux mixture were the best, bearing $38 \mathrm{I} / 2 \mathrm{lb}$. of sound berries, but noperfect bunches. The four rows sprayed with eau celeste bore $27 \mathrm{lb}$. of sound berries. The six rows not sprayed bore $32 \frac{1}{4}$ lb. of sound berries. The percentage of grapes rotted was not estimated.

In 1890 , summer-pruning in connection with spraying was tried:

Two rows were sprayed with the Bordeaux mixture without pruning.

One row was sprayed with Bordeaux mixture and kept pruned all summer.

Two rows were sprayed with eau celeste without pruning.

One row was sprayed with eau celeste and kept pruned.

Two rows were sprayed with carbonate of copper.

Two rows were kept pruned and not sprayed.

Four rows were neither pruned nor sprayed.

The spraying was done May 2oth, June 18 th and June $23 \mathrm{~d}$, and July 5 th.

No rot was found on the grapes by the examinations made up to June Ioth. It was the intention to spray again on the $\mathrm{I} I \mathrm{th}$, but rains prevented that day, and for several succeeding days. A careful examination made June 17 th showed that at least half the berries had begun to rot, the diseased spots varying in size from mere points to spots $1 / 8$ in. in diameter. 
The number of grapes rotting continued to increase after the spraying of the $\mathrm{r} 8 \mathrm{th}$, and a few apparently started to rot after the spraying of June 23d. The rot did not appear to spread to new berries during July or August, but a few second crop berries rotted during the damp weather of October.

The subjoined table of results indicates that, while the spraying may not be a specific, it is at least a partial remedy for the black rot; it also shows that on vines kept summer-pruned and sprayed, the grapes rotted less than on those sprayed and not pruned; while on those pruned and not sprayed the grapes rotted much worse than on those neither pruned nor sprayed; that grapes on vines not cultivated, the weeds being occasionally mowed off, rotted more than on those kept clean by cultivation.

\begin{tabular}{|c|c|c|c|}
\hline T- & $\begin{array}{l}\text { Per cent., } \\
\text { rotted, } \\
\text { estimate. }\end{array}$ & $\begin{array}{l}\text { Per cent.", } \\
\text { good, } \\
\text { estimate. }\end{array}$ & $\begin{array}{l}\text { Av. yield per } \\
\text { vine, } \\
\text { lb. }\end{array}$ \\
\hline $\begin{array}{l}\text { Two rows vines not sprayed or pruned........ } \\
\text { Two rows sprayed with Bordeaux, not pruned }\end{array}$ & 82. & 18 & 1.14 \\
\hline Two rows sprayed with Bordeaux, not pruned & 67.5 & 32.5 & 39 \\
\hline One row sprayed with Bordeaux, pruned...... & 43 & 57 & \\
\hline One row sprayed with eau celeste, pruned..... & & & 3.05 \\
\hline Two rows sprayed with eau celeste, not pruned...... & 63.5 & 36.5 & 2.67 \\
\hline $\begin{array}{l}\text { Two rows pruned, not sprayed ...................... } \\
\text { Two rows sprayed with carbonate of copper, not }\end{array}$ & 90 & 10 & .53 \\
\hline 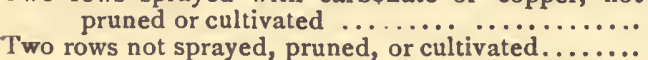 & $\begin{array}{l}84 \\
93.5\end{array}$ & $\begin{array}{l}16 \\
6.5\end{array}$ & .9 \\
\hline
\end{tabular}

The place in which the carbonate of copper was used does not give a fair test of its efficiency as a preventive.

The advantage of summer-pruning vines to be sprayed seems to come from the greater certainty of getting the fungicide upon the berries. Grapes pruned and not sprayed rot worse than those not pruned or sprayed, because the dew forms on the exposed fruit and not on that covered over with leaves, the dewdrops affording the proper condition of moisture for the growth of the spores of the rot. The berries can be reached properly by the spray without summer-pruning, if the spray nozzle is thrust in among the vines instead of being held on the outside. The pruning of itself does harm rather than good.

As a result of the work done here it is recommended that vineyards be kept well cultivated, and that where they have been previously subject to black rot they be thoroughly sprayed with the Bordeaux mixture or with eau celeste as often as the season may demand. If the season continues dry all the time, there is little chance for the rot to develop; but a spell of warm, rainy weather, coming at any time from the setting of the fruit to the time of ripening, may start the disease into active work. The disease cannot be cured but must be prevented. The first spraying may be done in the spring as soon as the first leaves are developed, and it is commonly recommended to repeat it three to six times.

The Bordeaux mixture leaves a greenish sediment on the fruit, and when applied in large amount or late in the season, injures it either for market or home use. The sediment may be removed by dipping the berries in a wash made of one quart of cider vinegar to five gallons of water. The other fungicides leave no apparent sediment on the fruit. 
The work done at other places, and especially that under the direction of the U. S. Department of Agriculture, has been so successful that there is no room to doubt the profitableness of spraying grape vines when they are infested with either the black rot or downy mildew. In a recent report issued by the Department [Journal of Mycology, Vol. VI., No. 3] is given an account of an experiment in spraying, in which a vineyard, so badly infested that it had been abandoned for five years, after being pruned and cleaned up, was divided into five plats, four of which were treated with different fungicides and the fifth left as a check.

On plat.one, sprayed eight times with Bordeaux mixture, 99.2 per cent. of the crop was saved.

On plat two, sprayed eight times with ammoniacal carbonate of copper, 97.5 per cent. of the crop was saved.

On plat three, sprayed eight times with carbonate of copper in suspension, 93.64 per cent. of the crop was saved.

On plat four, sprayed three times with ammoniacal carbonate of copper, 97.27 per cent. of the crop was saved.

On plat five, which received no preventive treatment, not a single bunch was produced which was fit for market.

Reports nearly as favorable come from several other sources. It would appear from all accounts that to attain satisfactory results persistent application is necessary.

Formulas. The following formulas for fungicides are taken from the 'Horticulturists' Rule Book, edited by Professor L. H. Bailey:

Ammoniacal carbonate of copper. Into a vessel having a capacity of $2 \mathrm{qt}$. or more, put one qt. of commercial ammonia (strength $22^{\circ}$ Baumé); add 3 oz. carbonate of copper; stir rapidly for a moment and the carbonate of copper will dissolve in the ammonia, forming a very clear liquid. This concentrated liquid may be kept indefinitely. For use, dilute to 22 gall.

Bordeaux mixture. Dissolve $6 \mathrm{lb}$. of sulphate of copper in 16 gall. of water. In another vessel slake $4 \mathrm{lb}$. of quick lime in 6 gall. of water. When the latter mixture has cooled pour slowly into the copper solution, care being taken to mix the fluids thoroughly by constant stirring. Prepare some days before using. Stir before applying.

Eau celeste. Dissolve one pound of sulphate of copper in 2 gall. of water. When completely dissolved and the water has cooled add $11 / 2$ pt. of commercial ammonia When ready to use dilute to 22 gall.

A second method of preparing eau celeste: Dissolve I lb. of sulphate of copper in 2 gall. of water. In another vessel dissolve I lb. of carbonate of soda. Mix the two solutions, and when chemical action has ceased add $11 / 2 \mathrm{pt}$. of commercial ammonia. For use, dilute to 22 gall. A modification of this latter method is $21 \mathrm{~b}$. sulphate of copper, $21 / 2 \mathrm{lb}$. carbonate of soda, and $1 \frac{1}{2} \mathrm{pt}$. of commercial ammonia, prepared as before.

The Bordeaux mixture is more difficult to use than either of the others, and in the hands of some of our best experimenters, has given little, if any better results.

Machines. For spraying in a small way some one of the forms of knapsack pumps is most convenient. For work on a larger scale, a machine mounted on wheels is better. We have been using the past year the 
Eureka sprayer, and it has given excellent satisfaction. Good machines may be found advertised in almost any agricultural or horticultural paper.

\section{General Conclusions.}

The various compounds of copper offer efficient protection to many cultivated crops against the exceedingly destructive ravages of fungous parasites. Without treatment, these rots, rusts, mildews, and blights frequently destroy a large proportion of, or even the entire, products of fields and fruit plantations. The applications in the shape of watery sprays are made so readily and with so little expense in money and labor that every one interested should at once undertake the work. The practical results already attained, constitute the greatest advance made in recent times in the application of science to horticulture. A little welldirected effort may be confidently expected to return a hundred, or a thousand times its cost. Still there is need for much vigilance and careful attention to every detail. Mistakes may be made even then, and sometimes failures may occur for which existing knowledge may offer no explanation. But we should persevere, gain all possible information upon the subject, and watch well the effects in every test. In this way, every one may hope to conquer, practically, these insidious and, heretofore, invincible foes.

If the readers of this paper desire further information concerning the subject, write to the Agricultural Experiment Station, Champaign, Illinois.

T. J. Burrill, PH. D., Horticulturist and Botanist.

. G. W. McCluer, B. S., Assistant Horticulturist.

All communications intended for the Station should be addressed, not to any person, but to the

Agricultural Experiment Station, Champaign, Illinois.

The bulletins of the Experiment Station will be sent free of all charges to persons engaged in farming who may request that they be sent.

SELIM H. PEABODY, President Board of Direction. 





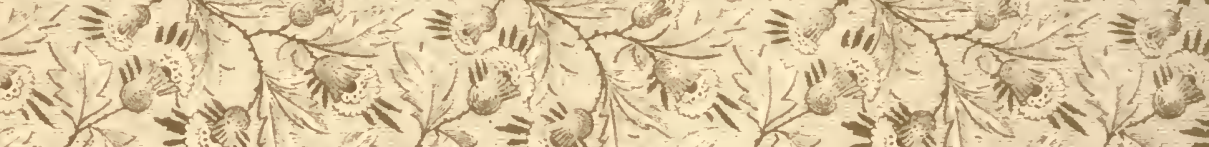

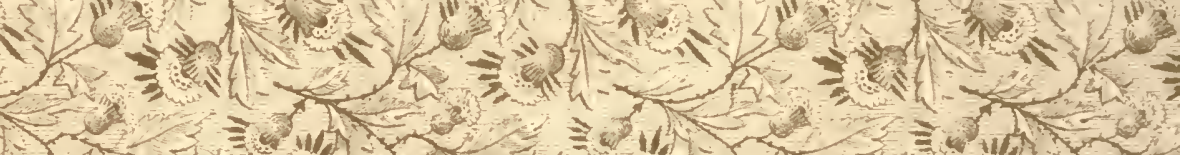

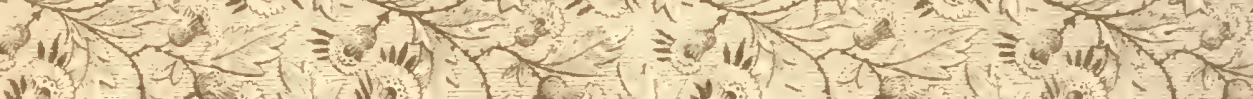

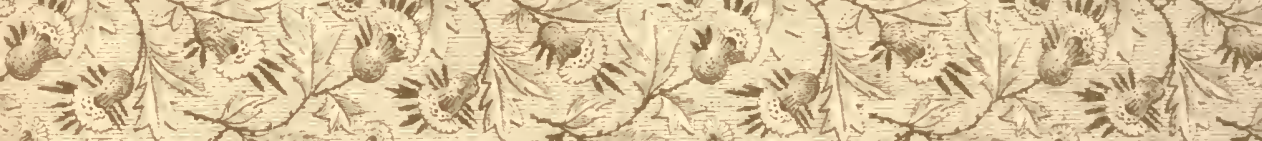

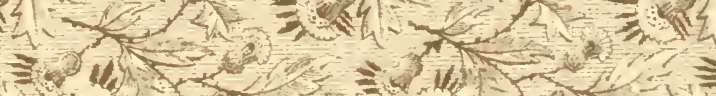

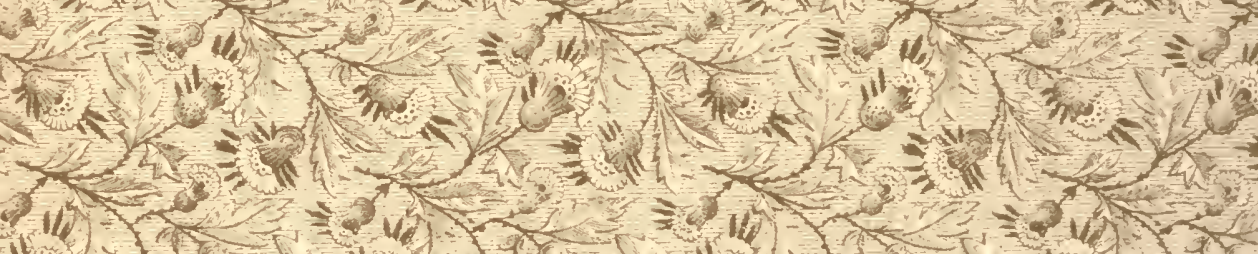

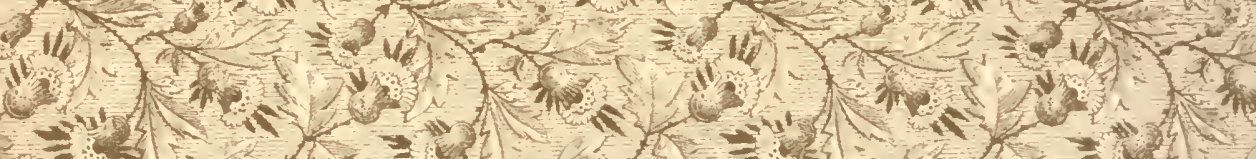

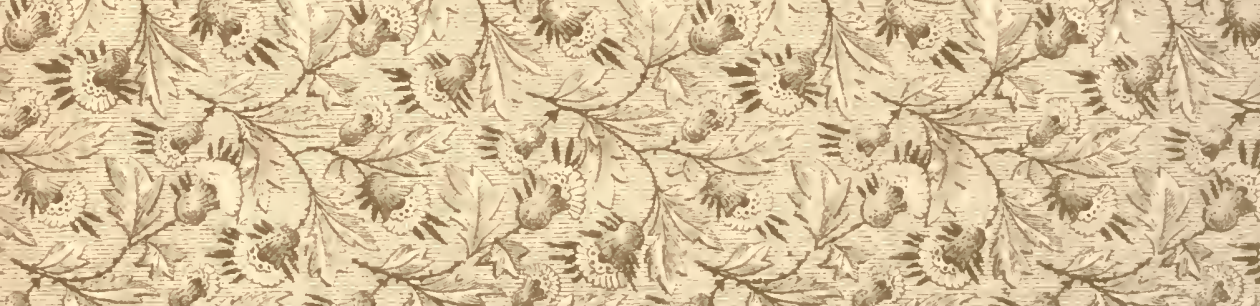

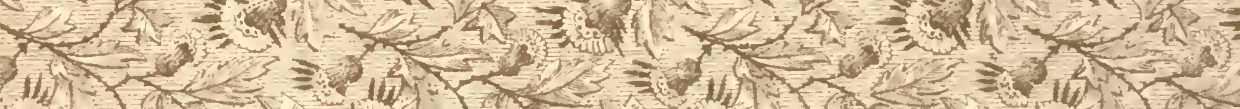

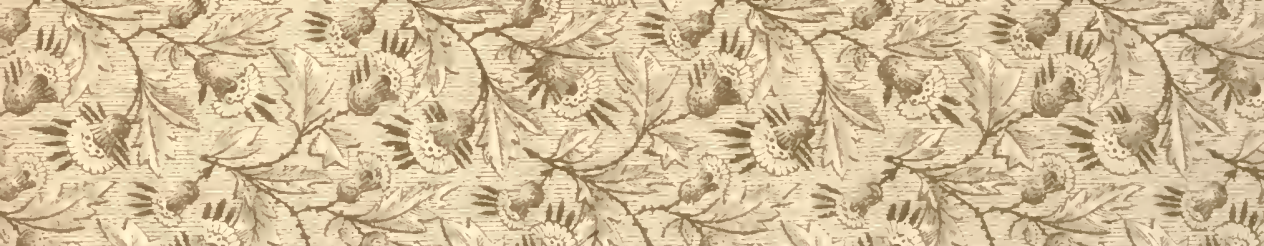

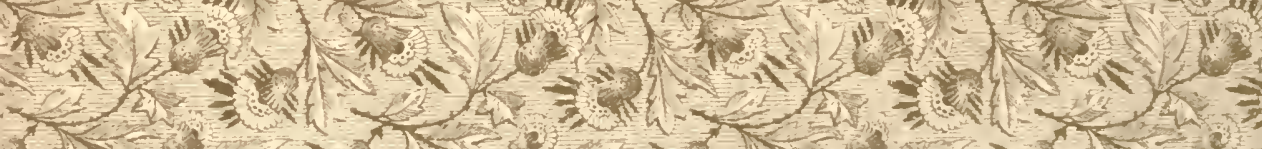
$y$

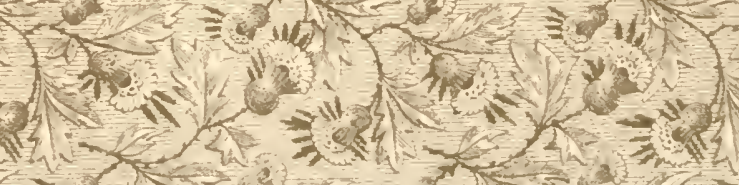

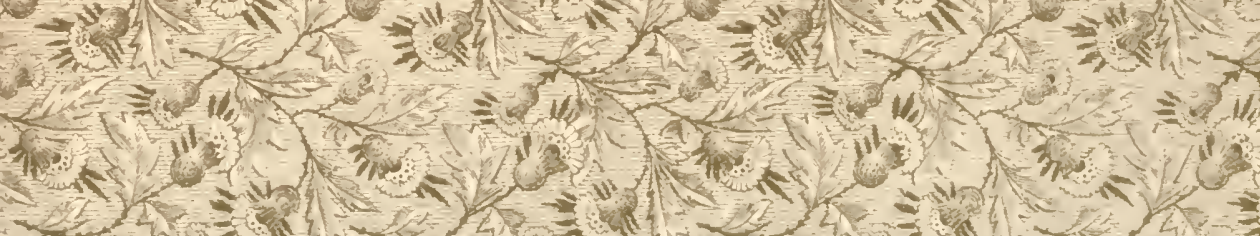
it ly

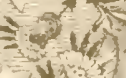
$\$ 414$ vi: 1) 1) 


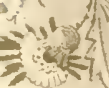

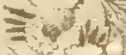

(1)

$$
\begin{aligned}
& \text {, }
\end{aligned}
$$

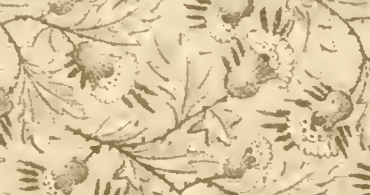

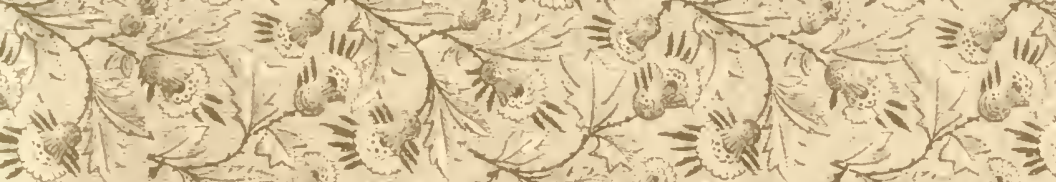

19.<smiles>[AlH2]</smiles>

1) $\geqslant 4$ (1) is न $7 u_{1}$

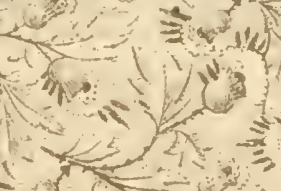
$560=$

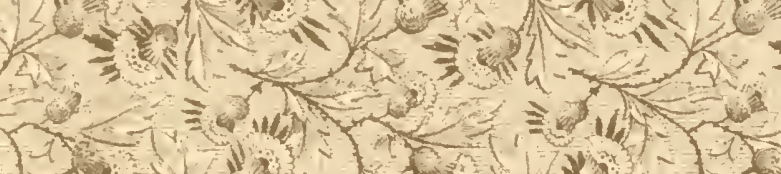

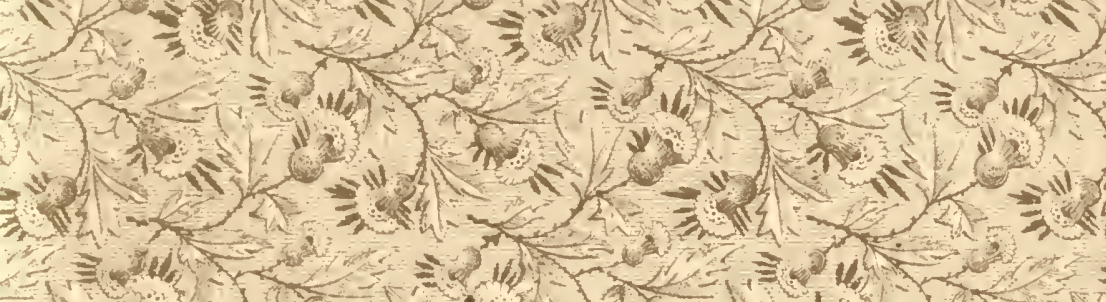
(n) 
